\title{
Formulation of Orally Disintegrating Tablets of Captopril as Superdisintegrant using Corncob (Zea mays L.)
}

\author{
Gabena Indrayani Dalimunthe ${ }^{1 *}$ (D), Samran Samran ${ }^{2}$ (D), Najarul Susanto ${ }^{1}$, Ridwanto Ridwanto ${ }^{1}$, Kasta Gurning $^{3}$ (D) \\ ${ }^{1}$ Department of Pharmaceutical Technology, Faculty of Pharmacy, Universitas Muslim Nusantara Al Washliyah, Medan, \\ Indonesia; ' ${ }^{2}$ Department of Pharmaceutical Technology, Sekolah Tinggi IImu Kesehatan Indah Medan, Medan, Indonesia; \\ ${ }^{3}$ Departement of Pharmacy, Sekolah Tinggi IImu Kesehatan Senior Medan, Medan, Indonesia
}

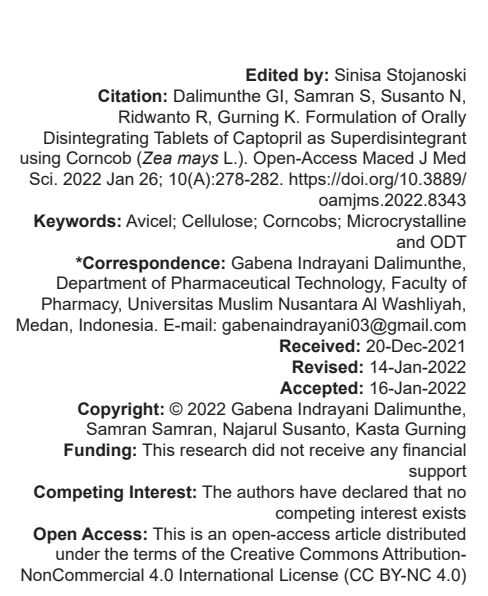

Abstract

AIM: This study aimed to make corncobs the basic material for the manufacture of microcrystalline cellulose.

METHODS: Manufacture of corncob cellulose microcrystals (CCMs) by isolating alpha-cellulose from corncobs, then hydrolyzed with $\mathrm{HCl} 2.5 \mathrm{~N}$. The yield of CCMs of $14.51 \%$ can be used as orally disintegrating tablet (ODT) and has similarities with Avicel as standard comparison.

RESULTS: Both organoleptic results were $\mathrm{pH} 5.6$ and 6.54; drying shrinkage $3.33 \%$ and $4.39 \%$; total ash content $0.17 \%$ and $0.02 \%$; and water solubility $0.9 \%$ and $0.12 \%$. Furthermore, the real specific gravity is 0.317 and $0.306 \mathrm{~g} / \mathrm{cm}^{3}$, incompressible density is 0.379 and $0.375 \mathrm{~g} / \mathrm{cm}^{3}$, the true density is 1.291 and $1.206 \mathrm{~g} / \mathrm{cm}^{3}$, Hausner index is 1.195 and 1.225 , compressibility index is 19.55 and $22.55 \%$, and porosity is 75.5 and $74.6 \%$.

CONCLUSION: Captopril ODT tablet preparations with CCM as filler have almost the exact tablet evaluation results compared to Avicel and to meet the requirements.

\section{Introduction}

Corn is one of the world's largest agricultural productions whose seeds are processed into various main food preparations such as canned corn seeds, and corn silk by-products, husks, and cobs. For every $100 \mathrm{~kg}$ of corn kernels produced, the cob content is $18 \mathrm{~kg}$ and most of it is used as feed, into organic fertilizer and into waste [1]. The content contained in corncobs includes cellulose $39.1 \%$, hemicellulose $42.1 \%$, lignin $9.1 \%$, protein $1.7 \%$, and ash $1.2 \%$ [2]. In addition, corncobs are also reported to have potential utilization as natural antioxidants and absorbents [3], [4]. The high content of corncobs can be applied in the cosmetic field food and pharmaceutical industry [5]. The cellulose content can be converted into corncobs microcrystalline by mineral acid degradation [6], [7].

The microcrystalline content obtained is widely used in the food, cosmetic and pharmaceutical industries, suspension stabilizers, fat substitutes, texture regulators, and other fillers [7], [8], [9]. The microcrystalline content produced from various isolated raw materials varies. Oral drug delivery systems are of great interest in drug development. One of the factors in oral drug delivery is the rate of absorption and duration of absorption. Modifications in the development of drug preparations require sustained-release absorption to maintain the drug in its absorption site at the absorption site to achieve maximum absorption and also not to saturate the transport traversed in the mechanism [9].

Captopril is one of the drugs commonly used in the treatment of hypertension. This drug is taken orally and works by inhibitory the action of the angiotensin converting enzyme to treat high blood pressure, blood pressure, heart failure, and prevention of kidney failure due to hypertension and diabetes. Disadvantages of the available drug captropil in the formulation do not apply the principle of slow release drug and fast disintegration time [9], [10]. Therefore, the purpose of this study was to formulate captopril drug preparations 
with fillers using microcrystalline corncobs compared to Avicel PH 102.

\section{Experimental}

\section{Materials}

The materials used were 20 mesh sieves, oven, blender (National), pH meter, weighing bottle, desiccator, porcelain crucible, pycnometer (Merk Iwaki), funnel, hardness tester (Vanguard type YD-2), friabilator tester (Erweka), disintegrating tester (Hanson research), Petri dishes, analytical balance (Sartorius), spectrophotometry (Shimadzu), dissolution test equipment (Hanson Research), and other glassware and the chemicals used were Captopril ${ }^{\circledR}$, AvicelPH $102^{\circledR}$, sodium hydroxide (Merck), distilled water, sodium hypochlorite (Merck), hydrochloric acid (Merck), starch (pro analysis), lactose anhydrous (Merck), sodium starch glycolate (Pharmaceutical Grade), mannitol DC (Merck), aspartame (Merck), Mg stearate (Merck), talc powder (Merck), and mint flavor.

\section{Sample preparation}

Corncobs cleaned of impurities, washed, drained, and aerated, then dried in a drying cabinet at a temperature of $60^{\circ} \mathrm{C}$ until brittle. Corncobs were ground using a blender and sieved using a size of 20 mesh. The sieved corncob powder was stored in a tightly closed plastic container and stored in a pharmaceutical biotechnology laboratory before use.

\section{$\alpha$-cellulose isolation process}

A $100 \mathrm{~g}$ corncobs powder added $1.5 \mathrm{~L}$ of $\mathrm{NaOH} 4 \%$ and heated for $2 \mathrm{~h}$ at $100^{\circ} \mathrm{C}$. After that, it was filtered and the residue was washed with distilled water until the $\mathrm{pH}$ was neutral. The residue was bleached with $1 \mathrm{~L}$ of sodium hypochlorite $2.5 \%$ for $24 \mathrm{~h}$ at room temperature, then filtered and the residue was washed with distilled water until the $\mathrm{pH}$ was neutral followed by the addition of $650 \mathrm{~mL}$ of $\mathrm{NaOH} 17.5 \%$ and heated at $80^{\circ} \mathrm{C}$ for $1 \mathrm{~h}$. Subsequently, it was bleached again with $500 \mathrm{~mL}$ sodium hypochlorite of $2.5 \%$ and heated at $100^{\circ} \mathrm{C}$ for $5 \mathrm{~min}$. It was filtered and the residue was washed with distilled water until the $\mathrm{pH}$ was neutral and then dried in an oven at $60^{\circ} \mathrm{C}$ [6], [11].

\section{Manufacturing of corncob cellulose microcrystalline}

A $50 \mathrm{~g}$ of alpha-cellulose was hydrolyzed with 1.2 L of $\mathrm{HCl} 2.5 \mathrm{~N}$ by boiling for $15 \mathrm{~min}$ in a glass beaker. Then, it was poured into cold water while vigorously stirring with a magnetic stirrer at a speed of $300 \mathrm{rpm}$ for $10 \mathrm{~min}$ and then allowed to stand overnight and filtered. Corncob cellulose microcrystals (CCMs) were washed with distilled water until neutral, then dried in an oven at a temperature of $57-60^{\circ} \mathrm{C}$ for $60 \mathrm{~min}$ and then ground [12], [13], [14].

\section{Captopril orally disintegrating tablet (ODT) tablet manufacturing}

The modified ODT was made using $\mathrm{FI}$ (microcrystalline) cellulose from corncob, filler $F$ II (Avicel PH-102) captopril, DC mannitol, aspartame, sodium starch glycolate, Mg stearate, talc, and mint flavor (Table 1). The two components are put into the mortar and then stirred until homogeneous. Preformulation testing was continued by evaluating the results of captopril ODT tablets [15].

Table 1: Captopril ODT tablet formula

\begin{tabular}{lll}
\hline Material name $(\mathrm{mg})$ & $\mathrm{F} \mathrm{I}$ & $\mathrm{F} \mathrm{II}$ \\
\hline Captopril & 12.5 & 12.5 \\
CCM & 78 & - \\
Avicel PH 102 & - & 78 \\
Sodium starch glycolate & 13 & 13 \\
Mannitol & 19.5 & 19.5 \\
Aspartame & 3.9 & 3.9 \\
Stearate Mg & 1.7 & 1.7 \\
Talc & 1.3 & 1.3 \\
Pepper mint & $\mathrm{q} . \mathrm{s}$ & $\mathrm{q}, . \mathrm{s}$ \\
Total & 130 & 130 \\
\hline ODT: Orally disintegrating tablet. CCM: Corncob cellulose microcrystal &
\end{tabular}

\section{ODT tablet evaluation}

Evaluations carried out on ODT included weight uniformity test, tablet hardness test, friability test, disintegration time test, and wetting test [10], [16], [17]. Uniformity was determined by taking 20 tablets and cleaned and then weighed each tablet. Hardness test using a hardness tester by taking six samples of tablets and referring to the tablet hardness requirements of $0.1-$ $0.3 \mathrm{kP}(1 \mathrm{~kg}=1 \mathrm{kP})$. Friability test aims to measure the friability of tablets by taking 10 tablets of ODT samples, cleaned and put into the friabilator tester, and rotated at a speed of 25 revolutions/minute for $4 \mathrm{~min}$, then weighed. The value of tablet friability is quite good $0.1-$ $0.9 \%$. Disintegration time testing was carried out on six tablet samples, used $800 \mathrm{ml}$ of water with a temperature of $37^{\circ} \mathrm{C} \pm 2^{\circ} \mathrm{C}$ as the medium, and put one tablet in each tube from the basket. Then, the tool is run with a frequency of up and down from the basket 30 times/ $\min$. At the end of the time limit as indicated in the monograph, lift the basket and examine the six tablets. All tablets must be completely crushed. Requirements: The time required to crush the tablet is $<1 \mathrm{~min}$.

\section{Results and Discussion}

\section{Manufacture of CCM}

Corncob powder $100 \mathrm{~g}$ obtained $18.5 \mathrm{~g}$ of alpha cellulose, then continued in the hydrolysis 
stage and obtained $14.51 \mathrm{~g}$ of microcrystalline cellulose $(14.51 \%)$ (Figure 1). This shrinkage occurs due to the loss of lignin, hemicellulose, and other compounds when alpha-cellulose undergoes a hydrolysis reaction.

The organoleptic results of CCM compared with Avicel had similarities including odor, white color, and tasteless and had a $\mathrm{pH}$ of 5.6 while Avicel had 6.54 and met the standard for medicinal raw materials. The physicochemical properties of CCM and Avicel are presented in Table 2.

Table 2: Physicochemical properties of CCM and Avicel

\begin{tabular}{lll}
\hline Parameter & CCM & Avicel \\
\hline Organoleptic & $\begin{array}{l}\text { Odorless, white, } \\
\text { and tasteless }\end{array}$ & $\begin{array}{l}\text { Odorless, white, } \\
\text { and tasteless }\end{array}$ \\
pH & 5.6 & 6.54 \\
Drying shrink & $3.33 \%$ & $4.39 \%$ \\
Solubility of substances in water & $0.9 \%$ & $0.12 \%$ \\
Total ash content & $0.17 \%$ & $0.02 \%$ \\
Specific weight & & \\
$\quad$ Real specific gravity $\left(\mathrm{g} / \mathrm{cm}^{3}\right)$ & 0.317 & 0.306 \\
$\quad$ Compressed specific gravity $\left(\mathrm{g} / \mathrm{cm}^{3}\right)$ & 0.379 & 0.375 \\
$\quad$ Correct specific gravity $\left(\mathrm{g} / \mathrm{cm}^{3}\right)$ & 1.291 & 1.206 \\
Hausner index $(\%)$ & 1.195 & 1.225 \\
Compressibility index $(\%)$ & 19.55 & 22.55 \\
Porosity $(\%)$ & 75.5 & 74.6 \\
\hline CCM: Corncob cellulose microcrystal & &
\end{tabular}

CCM: Corncob cellulose microcrystal

\section{ODT Pre-formulation}

The results of the pre-formulation tests carried out showed that CCM and Avicel met the requirements, had almost the same flow time, and had uniformity of granules. The time required for the granules to flow must be $<10 \mathrm{~s}$. The results of the pre-formulation test of captopril ODT tablets from CCM with Avicel are presented in Table 3. The results of the evaluation of the ODT granules from the angle of repose and the index for CCM and Avicel showed that they met the specified requirements.

Table 3: Captopril ODT tablet pre-formulation test results

\begin{tabular}{llll}
\hline Formula & Flowability time (second) & Angle of friction $\left({ }^{\circ}\right)$ & Tab index $(\%)$ \\
\hline CCM & 1.65 & 21.02 & 16.23 \\
Avicel & 1.48 & 20.58 & 18.64 \\
\hline
\end{tabular}

ODT: Orally disintegrating tablet, CCM: Corncob cellulose microcrystal

\section{Formulation and ODTs of captopril drugs}

The results of the captopril tablet formulations of CCM and Avicel are shown in Figure 2. The results of the evaluation showed uniformity of weights for CCM and Avicel (Table 4) and meet the requirements in accordance with the drug standards that have been determined. The formulation of captopril drug produced was in accordance with the dosage for use as a therapeutic drug.

Table 4: The results of the uniformity of the weight of the captopril drug

\begin{tabular}{lll}
\hline Observation parameters & Captopril tablets & \\
\cline { 2 - 3 } & CCM & Avicel \\
\hline Average weight $(\mathrm{mg})$ & 130.15 & 132 \\
The highest weight of 1 tablet (\%) & 1.51 & 2.05 \\
Lowest weight of 1 tablet (\%) & 1.15 & 1.41 \\
Lowest weight of 1 tablet (\%) & 1.51 & 1.31 \\
\hline CCM: Corncob cellulose microcrystal & &
\end{tabular}

The hardness and friability tests of the captopril CCM and Avicel tablets formulation results are shown in Table 5. The purpose of the hardness test was to provide an overview of resistance to mechanical shock during the distribution process. In addition, the tablet hardness test also provides an overview of the speed of disintegration and dissolution of the tablet adsorption. Friability testing aimed to ensure the consistency of the weight during the production process until it reaches the consumer within the specified time, the results show compliance with Indonesian drug formulation standards.

Table 5: Evaluation of the formulated captopril CCM and Avicel tablets

\begin{tabular}{lll}
\hline Tablet & Hardness & Friability (\%) \\
\hline CCM & 4.92 & 0.76 \\
Avicel & 3.5 & 0.68 \\
\hline CCM: Corncob cellulose microcrystal & &
\end{tabular}

In vitro disintegrating test data with the use of disintegration tester, in vitro model consists of two tests; Model I (disintegration testes had a mimicking up and down peristaltic movement) whereas Model II without, and in vivo model (in the oral cavity) is shown in Table 6. In vitro disintegration time test of tablets used as ODT medium was water. This was because ODT is designed to disintegrate in the oral cavity [14]. Table 6 data showed that the in vivo disintegration time in the mouth for all ODT formulas is the fastest disintegration time compared to the other two types of disintegration time. This was thought to be due to the movement of the tongue, the alkaline $\mathrm{pH}$ of the saliva, and the presence of the enzyme ptyalin which
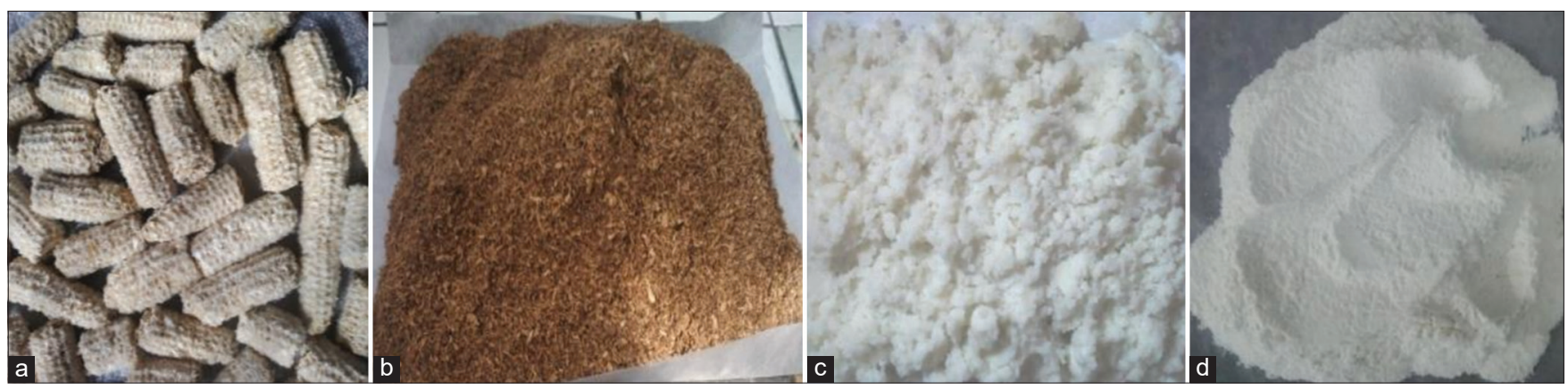

Figure 1: CCM manufacturing process; (a) corncob, (b) corncob powder, (c) corncob alpha-cellulose, and (d) CCM. CCM: Corncob cellulose microcrystal 


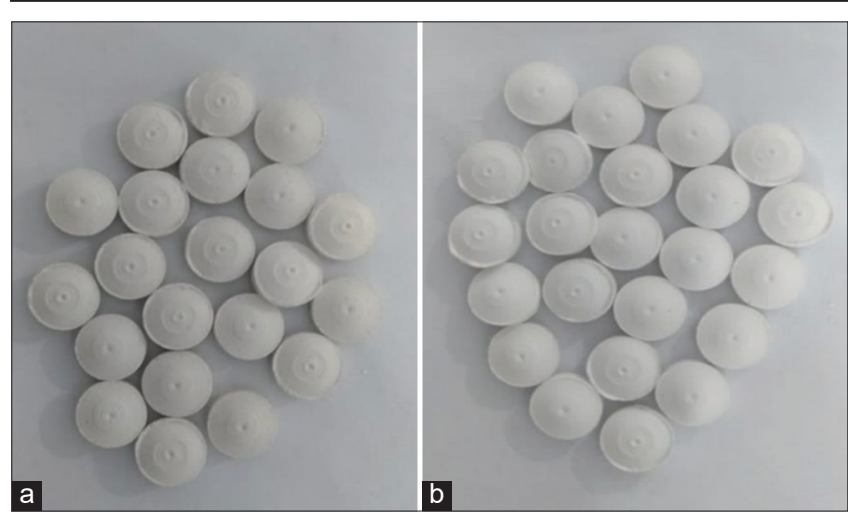

Figure 2: Captopril tablet formulation results from CCM and Avicel; (a) CCM and (b) Avicel. CCM: Corncob cellulose microcrystal

helps speed up the disintegration of the tablet in the mouth.

Table 6: Evaluation of the ODT time formulated CCM and Avicel captopril tablets

\begin{tabular}{lll}
\hline Formulated captopril CCM & Test & Disintegrate time (second) \\
\hline CCM & Model I & 18.46 \\
& Model II & 37.15 \\
\multirow{2}{*}{ Avicel } & In vivo & 12.26 \\
& Model I & 12.22 \\
& Model II & 31.12 \\
& In vivo & 9.27 \\
\hline
\end{tabular}

\section{Conclusion}

The results of the evaluation of the captopril ODT tablet formulation with CCM as a filler have similarities with Avicel as a standard filler in tablets and all the parameters of the tablet requirements are met. The results of this study indicate that CCM can be used as a substitute for Avicel as a filler in the formulation of ODT tablets and further research is needed to maximize the function of CCM in tablet formulations.

\section{Acknowledgment}

Thank you for the assistance provided by our students, namely, Sara Meutia, Yulizah Abidin Matondang, and Nurhayati Br. Karo in carrying out this research. Hopefully with the research experience can guide you in the further research.

\section{References}

1. Lau T, Harbourne N, Oruna-Cancha J. Valorisation of swwer corn (Zea mays) cob by extraction of valuable compounds. Int $\mathrm{J}$
Food Sci Technol. 2019;54(4):1240-6.

2. Ashour A, Amer M, Marzouk A, Shimizu $K$, Kondo $R$, El-Sharkawy S. Corncobs as a potential source of functional chemicals. Molecules. 2013;18(11):13823-30. https://doi. org/10.3390/molecules 181113823

PMid:24217325

3. Suryanto E, Momuat LI, Yudistira A, Wehantouw F. The evaluation of singlet oxygen quenching and sunscreen activity of corncob extract. Indones J Pharm. 2013;24(4):267-76. https:// doi.org/10.14499/indonesianjpharm24iss4pp2670

4. Isa I, Setiawati E, Mohammad E, Kunusa W. Ultilization of corncob cellulose isolate (Zea mays) as adsorbent of heavy metal copper and cadmium. IOP Conf Series Earth Environ Sci. 2020;589:1-10. https://doi. org/10.1088/1755-1315/589/1/012035

5. Aprilia NA, Mulyati S, Alam PN, Razali N, Zuhra, Farmawati, et al. Preparation and characterization of sugarcane bagasse nanocellulose crystalline using acid hydrolysis with and without ultrasonication. Rasayan J Chem. 2021;14(1):601-7. https://doi. org/10.31788/rjc.2021.1415920

6. Singh HK, Patil T, Vineeth SK, Das S, Pramani A, Mhaske ST Isolation of microcrystalline cellulose from corn stover with emphasis on its constituents: Corn cover and corn cob. Mater Today. 2019;27(1):589-94. https://doi.org/10.1016/j. matpr.2019.12.065

7. Shao X, Wang J, Liu Z, Hu N, Liu M, Xu Y. Preparation and characterization of porous microcrystalline cellulose from corncob. Ind Crops Prod. 2020;151:1-6. https://doi.org/10.1016/j. indcrop.2020.112457

8. Abiaziem CV, Williams AB, Inegbenebor Al, Onwordi CT, EhiEromosele CO, Petrik LF. Isolation and characterisation of cellulose nanocrystal obtained from sugarcane peel. Rasayan J Chem. 2020;13(1):177-87. https://doi.org/10.31788/RJC.2020.1315328

9. Suesat J, Suwanruji P. Preperation and properties of microcrtstalline cellulose from corn residues. Adv Mater Rese. 2011;332-334:1781-4. https://doi.org/10.4028/www.scientific. net/AMR.332-334.1781

10. Abbasi S, Yousefi G, Ansari AA, MohammadiSamani S. Formulation and in vitro evaluation of a fastdisintegrating/sustained dual release bucoadhesive bilayer tablet of captopril for treatment of hypertension crises. Res Pharm Sci. 2016;11(4):274-83. https://doi. org/10.4103/1735-5362.189284

11. Ohwoavworhua FO, Adelakun TA. Non-wood fibre production of microcrystalline cellulose from sorghum caudatum: Characterisation and tableting properties. Indian J Pharm Sci. 2010;73(3):295-301. https://doi. org/10.4103/0250-474X.70473

12. Zaky AA, Elewah HA. Design and optimization of captopri sublingual tablets: Enhancement of pharmacokinetic parameters in human. Az J Pharm Sci. 2016;53:90-107.

13. Rojas J, Lopez A, Guisao S, Ortiz C. Evaluation of several microcrystalline celluloses obtained from agricultural by-products. J Adv Pharm Technol Res. 2011;2(3):144-50. https://doi.org/10.4103/2231-4040.85527

14. Parfati N, Rani KC, Charles N, Geovanny V, Paramartha DP. Formulasi orally disintegrating tablet atenolol- $\beta$ siklodekstrin menggunakan Co-process superdisintegran crospovidone sodium starch glcolate. Med Pharm Indones. 2017;1(4):197-203.

15. Kelana AS, Kusuma AP, Indrati O. Formulation and evaluation of kaptopril tablets using threaded amylum tubes and HPMC as filters and binders of direct method. Eksakta. 2018;18(1):8-18. https://doi.org/10.20885/eksakta.vol18.iss1.art2

16. Fu $\mathrm{Y}$, Seong $\mathrm{HJ}$, Kimura $\mathrm{S}$, Park K. Orally fast 
disintegrating tablets: Developments, technologies, taste-masking and clinical studies. Crit Rev Ther Drug Carrier Syst. 2004;21(6):433-76. https://doi.org/10.1615/ critrevtherdrugcarriersyst.v21.i6.10

PMid:15658933
17. Rani KC, Parfati N, Putri W. Formulation of orally disintegratin tablet atenol with sodium starch glycolate as superdisintegran. J Farmasi Komunitas. 2017;14(1):55-64. https://doi. org/10.24071/jpsc. 141564 